\title{
Transforming Early Learning Vision into Action in Ontario, Canada
}

\author{
Jim Grieve \\ Ontario Ministry of Education \\ Canada
}

\begin{abstract}
In Canada, the provinces are responsible for education. This article describes the approach that Ontario, Canada's most populous province, has taken to implement a new vision for early learning including universal full-day kindergarten for all children aged four and five and modernizing the province's childcare system. This new vision is based on the current neuroscience, child development research and international promising practices in early childhood education and care. The article chronicles the progress that has been made from 2009 to the present in implementing full-day kindergarten and provides an update about the current status of Ontario's childcare modernization activities.
\end{abstract}

Key words: kindergarten, childcare, Ontario, policy, play-based learning

\section{Early Learning Vision Based on International Research and Promising Practices}

Today, breathtaking findings by neuroscientists are showing that biology is the ultimate level playing field. The human brain at birth holds within it untold, often untapped, equal opportunity only slightly influenced by genetic determination.

At birth, an infant's brain is relatively undeveloped. Different types of research, such as infant brain imaging, consistently

Correspondence concerning this article should be addressed to Jim Grieve, Assistant Deputy Minister, Ontario Ministry of Education, 900 Bay Street, 24th Floor Mowat Block, Toronto, Ontario M7A 1L2, Canada. Electronic mail may be sent to Jim.Grieve@ontario.ca show the profound similarities among newborn human brains. Everyone starts out with basically the same brain. Many scientists now believe that 20 percent of a person's outcome in life is the result of innate brain capacity. The other 80 per cent is based on what happens after birth.

Unfortunately, the playing field does not remain level for very long. Around the world, research shows, the biggest indicator of how well a child will do in school is the income of the child's parents.

Canada is the one international exception. In Canada, a child's chances of doing well in school cannot be solely predicted by their parents' socioeconomic status. This fact demonstrates that Canada's education system and 
public policies are having an impact. At the same time, significant gaps still exist. According to Early Development Index (EDI) scores - an instrument used across Canada to measure early childhood development and school readiness-more than one-quarter of five-year-olds in Ontario are not ready to fully profit from their grade 1 learning experience.

A child's school readiness is a proven predictor of academic achievement later on; therefore, whatever measures are taken can to increase those EDI scores and reduce children's risk of difficulties throughout their schooling. Thus the new early learning vision is based, in part, on the goal of dramatically reducing early childhood risk.

\section{Vision Answers the Question - What is the Purpose of Early Learning?}

Ontario's vision for early learning addresses big questions: What is the purpose of early learning? What does it intend to achieve? Realistically, if the goal of education is to help each child maximize their potential, not yet close to achieving it, then what should be changed?

These are important questions, however not the only ones worth asking. One of the important aspects of the vision for early learning is that it is more than a school readiness strategy. It means more than just minimizing risk. Its focus is broader than academic outcomes. It is also more than just a labour market strategy-offering a more cost-effective childcare option to working parents.

The language of early learning is changing. At one time, early learning was considered in terms of helping children become "ready to learn." But now science proves that humans start learning even before birth. Thereafter, early learning was reframed as making sure children were "ready for school." However, now the question is whether the school is ready for the young children.

In Ontario, the vision is about ensuring that more children are better ready for life. It is based on the recognition-again from research, as well as experience-that the human brain has a biological need to learn - all through life. Consequently, the education system is should unearth and ignite children's passion, their intrinsic desire to learn, and the deep joy of discovery.

Another basis for Ontario's vision is the deep respect for childhood in itself. As the OECD report Starting Strong observes: "The challenge exists to focus more on the child and to show greater understanding of the specific developmental tasks and learning strategies of young children."

Within Canada, Ontario has been in the forefront of early learning and kindergarten education. Being the first province to introduce public kindergarten for four-year-olds in the 1950s, kindergartens have improved by better attuning to the needs of children. 
This is made possible by combining the expertise of certified teachers and registered early childhood educators, who focuson all aspects of early childhood development-emotional, social and physical, as well as intellectual.

The full-day kindergarten curriculum concentrates to engage the entire brain and the whold child. Based on research results, movement and social interaction encourage young children to build their brains, whereas sitting still and being silent tend to shut down the brain.

Thenew inquiry-driven play-based curriculum focuses on creating daily quality experiences tailored to the needs and developmental stage of each child. This means that every day, every classroom will look a little different, to give each young brain a more equal chance at optimal development. Mass customization, not mass standard-ization, can best harness the extraordinary potential of each child.

Literacy and numeracy will still be a main focus. However, literacy and numeracy are created in the brain most effectively through the synergy of biology and experience through meaningful, engaging play-based learning activities.

The human brain has a biological need to learn all throughout life, however, kindergarten is a pivotal timeto prepare for life and lay the foundation of lifelong learning. It is a time of transition for children and families. Done right, transitions can be a stimulus to growth and development. It is the government's job to make sure the transition and the program live up the vision.

\section{Making the Case for Early Learning during a Difficult Economy}

In October 2009, when the Ontario government announced the full-day kindergarten for four and five year olds at an annual operational cost of $\$ 1.5$ billion (not including capital funding), the world economy was struggling and the provincial government faced a large deficit. Why would the government commit to this significant new expenditure at such a difficult financial time? What can other jurisdictions learn from this experience about making the economic case for investing in early learning? The numbers speak for themselves-and strictly in fiscal terms, early learning is a sound investment.

Studies have demonstrated the overall value to society of investing in the early years. For example, Nobel-prize winner James Heckman, a professor of economics at the University of Chicago, has demonstrated a seven-to-one return on for every dollar spent on early education. This is an average for all of early learning throughout the preschool years. The younger we start, the higher the benefit. At-risk populations also see a much higher benefit.

Other studies have shown that every dollar invested in children before the age of six saves up to $\$ 17$ in future social service costs. The HighScope Perry Preschool study in the US has followed a group of individuals from age three up until today, who arenow about 40 years old. To date, the economic return to society for each person's early education is \$16.14 per dollar invested. These individuals presumably are only half way through their lives. Unfortunately, 
the reverse is also true. A number of studies have demon-strated that the cost of inadequate investment in early education can approach $\$ 300,000$ per child.

\section{Early Learning is about Improving Human Development}

Researches show that the benefits of investing in early learning go far beyond merely economic benefits. Children's early learning experiences have a profound effect on their development and their future wellbeing. There is a large and growing body of research that substantiates the positive effect of early learning on children's overall academic attainment, their financial stabilityand well-being as adults, and their abilities to make meaningful contributions to their community.

As the Canadian early learning pioneer Dr. Fraser Mustard said, early learning is about far more than brain development - it is about human development. According to research, early human development affects every part of the society andthe world. Health, educational attainment, economic wellbeing and much more depend on thekind of start given to the youngest members.

Many scientific studies show the connection between early learning and the health of individuals and communities. For example, a recent study in the American Journal of Public Health
(2011) found that children who received age-appropriate early learning from infancy had significantly better health. These findings were indepen-dent of IQ, educational attainment or socio-economic status. Early education reduced health risks like smoking and depression and improved a number of health outcomes throughout the indi-viduals' lives. The health benefits of early learning are dramatic, the main investigator indicated.

\section{Phased-in Approach Encourages Collaboration}

Ontario's new full-day kindergarten program reflects the intersection of research, international best practice and policy that integrates the needs of families, children, schools and other stakeholders. Beginning in September 2010, the new full-day kindergarten program was implemented gradually over a five-year period. With astaged approach, school boards, schools and teachers were given the time to prepare for the program. It was anticipated that great lessons would be learned from the first and second years of implementation that would prepare Ontario toward full implementation in September 2014.

In every aspect of thework, the success depended on the partners. The TF team meet regularly, consult with and provide information to hundreds of partner and stakeholder groups. Through advisory, reference and working groups, formal relationships are built with the partners. Beyond 
group meetings, one-to-one meetings with partner organizations are held at least once a year. Informal relationships with the partners are also important.For example, there are six early learning education officers who work in regional offices throughout the province (Ontario is geographically vast)-they connect directly with school boards and other partners.

A collaborative approach was taken deliberately-listening to the partners at every stage of policy and legislative development and implementation. Whenthe implementation of the new full-day kindergarten program began, the first step was to take to the road. Every week during the past three years, visiting communities across the province has been one of the tasks. Each year, more than 100 schools, childcare centres are visited and community coalition meetings attended.

Governmental staff who are responsible for policy and implement-ation of early learning have often been right alongside. Almost every member of the Early Learning Division has been on a least one school visit. From policy and administrative staff to those responsible for implementation, everyone has made it his/hermission to personally see and experience the program up close and personal. They have crawled around on the floor with the children, discovered how high a tower of blocks can be built before it tumbles, and played board games using a four-year-old's rules. This way, staff can see first-hand what sort of impact their work is having on classrooms around the province.

\section{New Governance Structure Brings Childcare and Kindergarten Together}

In May 2010, the Ontario government announced that childcare would become the responsibility of the Ministry of Education. This announcement fulfilled another part of the early learning vision. It also acknowledged an international govern-ance trend and promising practice of bringing early childhood education and care under the same authority as the education system.

This new governance structure was accomplished over a transition period of 20 months. The purpose was to create a more seamless and integrated system for young children and their families.Currently, there are two options for regulated or licensed childcare in Ontario:

- centre-based licensed childcare

- home-based childcare associated with a licensed private-home day care agency

Only 19 percent of Ontario children are in licensed care. The remaining 81 per cent of children are cared for by parents or other family members or are in informal, unlicensed care.Licensed centres have a registered early childhood educator in every room. The College of Early Childhood Educators was established in 2009. The college, modeled on similar organizations for other selfregulating professions such as doctors, lawyers and teachers, is a first in North America for early childhood educators.

Childcare in Ontario is funded mainly through parent fees. Provincial government funding provides subsidies 
for low-income families. The government also provides specific funds for other purposes, such as wage subsidies and support for children with special needs.

\section{Modernizing Childcare as a Top Priority for Ontario}

In 2011, the Ontario government made a platform commitment to "work with our partners to modernize Ontario's childcare system and support centres as they transition to offering affordable care to families with younger children." The Day Nurseries Act, which governs childcare, dates back to 1946 and has not been significantly updated in decades. In the summer of 2012, the Ontario government released a discussion paper, Modernizing Child Care in Ontario: Sharing Conversations, Strengthening Partnerships, Working Together, which invited input on long-term vision and objectives for childcare over the next three years.

The long-term vision for childcare includes the following elements:

- High-quality, accessible and coordinated early learning and childcare for children before they start school and for school-aged children

- Learning in safe and caring playbased environments

- System that promotes healthy, physical, social, emotional and cognitive development and focuses on early identification and intervention for children in need of supports
- Services located in or linked with schools to enhance seamlessness for children and families, where possible

The discussion paper outlined five main areas of government focus in modernizing childcare in Ontario:

i) Operating funding formula-To modernize the approach to operating funding within the next three years, the government will develop and implement a new, more transparent approach to funding that responds to demand for services, helps stabilize fees and improves reliability of childcare, to better support childcare operators and parents.

ii) Capital funding formula-To support childcare operators as they adapt to full-day kindergarten over the next three years, the government will pursue a capital funding approach that emphasizes childcare spaces in schools in order to increase seamlessness for children and convenience for families.

iii) Quality programs - Over the next three years, the government will work to enhance program quality and consistency by developing mandatory provincial program guidelines for childcare operators. We will also develop an updated framework to support children with special needs and offer new resources and information for parents and providers.

iv) Modernized legislative and regulatory framework-To put the childcare sector on the path towards modernization over the next three years, the government will propose 
legislative and regulatory amendments to reflect up-to-date evidence and experience and to support health, safety and quality for children, parents and providers.

v) Support accountability and capacitybuilding-As the government modernizes childcare over the next three years, we will improve data collection, enhance licensing procedures and develop supports for parents and operators to help us better evaluate outcomes, support sector capacity, reduce duplication and improve accountability.

\section{Sharing Promising Practices via Council of Ministers of Education, Canada}

Canada is comprised of 10 provinces and three territories, each autonomously responsiblefor education and childcare with no coordinating role being played by the federal government. However, within Canada, virtually every province and territory is focusing on early learning like never before. There's a real desire among jurisdictions to work together-to share ideas, resources, experiences and knowledge.

Through the Council of Ministers of Education, Canada, a working group on early learning has been established to share information between jurisdictions and to work collaboratively on early learning projects of mutual benefit.The working group has already completed an environmental scan, so that all of the members would be aware of the major policies and activities across Canada in early learning. Through the working group, a statement on play-based learning was authored, and in July 2012 was endorsed by all Ministers of Education in Canada. The group is now working on compiling a resource of promising practices in the area of parent engagement. This inter-jurisdictional collaboration serves to ensure that early learning remains a top priority for all ministries of education across Canada.

\section{Full-day kindergarten in Ontario at a Glance}

Universal full-day kindergarten for all four and five year olds in Ontario, Canada is being phased in over a fiveyear period of 2010 to 2014 .

- September 2010: 35,000 four and five year olds entered the first year of fullday kindergarten - about 15 per cent of the total kindergarten population.

- September 2011: 50,000 four and five year olds enrolled in nearly 800 schools-about 20 percent of kindergarten children.

- September 2012: 1,700 schools currently offer the program to 49 percent of kindergarten students - about 122,000 children.

- September 2013: 2,600 schools will offer full-day kindergarten to approximately 75 percent of kindergarten students.

Full-day kindergarten will be fully implemented and available to all 250,000 of Ontario's four- and five-year olds in September 2014. \$200 million in support from the Ministry of Education 
for the program in year $1, \$ 300$ million in year 2 and $\$ 675$ million in year 3 . To date, the government has allocated almost $\$ 1.4$ billion in capital funding to support the implementation of full-day kindergarten.

\section{Before and After School Programs}

Where there is sufficient interest from parents, schools with full-day kindergarten provide an integrated onsite program from about 7 a.m. until the start of school and after school until about 6 p.m. Costs of the program are covered by parent fees. Subsidies are available based on need and eligibility. Municipalities administer the subsidies for the program.Before and after school programs adhere to the Ministry of Education Extended Day Program document.

\section{Role of Teacher and Early Childhood Educator in Full-day Kindergarten}

\section{Classrooms}

The average class size of full-day kindergarten in Ontario is 26 students with a teacher and a registered early childhood educator, who work as a team. The two educators have a "duty to cooperate" on:

- planning for and providing education to students

- observing, monitoring and assessing the development of the students

- communicating with families

- maintaining a healthy physical, emotional and social learning environment

- performing all duties assigned to them by the principal

\section{Childcare in Ontario at a Glance}

There are two options for regulated childcare in Ontario:

- centre-based licensed childcare

- home-based childcare associated with a licensed private-home day careagency

Licensed childcare programs are operated by non-profit and for-profit providers, school boards, First Nations and municipalities. As of March 2012, there are:

- 4,922 licensed childcare centres

- 132 licensed private-home day care agencies

- 275,900 spaces in licensed childcare centres

- 17,000 children enrolled in homebased care associated with licensed private-home day care agencies

The Ontario Ministry of Education is responsible for funding, licensing and developing policy to support the provision of licensed childcare. The province provides funding to municipalities and First Nations for childcare fee subsidies, wage subsidies, special needs resourcing and administration. Forty-seven municipali-ties are responsible for planning and managing childcare services at the municipal level, within provincial legislation, regulations, standards and guidelines. The Ontario government provides funding to 56 First Nations, one Tribal Council and four transfer payment agencies for onreserve licensed childcare. 


\section{Childcare Funding}

Since 2003, provincial childcare funding has increased by 90 per cent, to more than $\$ 1$ billion. The government has introduced transition funding, growing to $\$ 51$ million annually at full implementation, to help the childcare sector deal with the impact of full-day kindergarten. In addition, the government is investing \$12 million over five years to help non-profit childcare centres make retrofits and renovations to serve younger children. In 2012-13, the government announced an additional $\$ 90$ million investment to transition and modernize the childcare sector as it adapts to full-day kindergarten. From 2012 to 2015, the government is investing \$113 million to convert school space for licensed childcare.

\section{Childcare Modernization}

The government is taking steps to realize its vision of a more seamless and integrated system to support young children and their families by modernizing childcare.To help inform the next steps of childcare modernization, the government has released a discussion paper - Modernizing Child Care in Ontario: Sharing Conversations, Strengthening Partnerships, Working Together (www.edu. gov.on.ca/childcare/modernizing.html). The discussion paper outlines the government's long-term vision for childcare and seeks feedback on targeted medium-term objectives to help achieve that vision over the next three years.

\section{Childcare Legislation}

The Day Nurseries Act is the legislation that governs licensed childcare in Ontario. It sets out requirements to protect the health, safety and well-being of children in care. The Child Care Quality Assurance and Licensing Branch of the Ministry of Education inspects licensed childcare programs at least once a year. Inspections are carried out to:

- assess compliance with the Day Nurseries Act

- investigate complaints, issue licenses and renew licenses

- monitor operators who are having difficulty meeting licensing standards

In Ontario, an adult may care for up to five unrelated children under the age of 10 without needing a license. (This is commonly referred to as informal childcare). Informal caregivers are not regulated or monitored. However, licensing staff will investigate complaints from the public about a person who might be providing care to more than five unrelated children without a licence.

\section{Council of Ministers of Education, Canada, Statement on Play-Based Learning}

At the recent World Conference on Early Childhood Care and Education, organizers, keynote speakers, scientists, experts and political figures underscored the enormous benefits of early learning CMEC agrees with this position and believes that purposeful play-based 
early learning sets the stage for future learning, health and well-being.

\section{Learning Through Play is Supported by Science}

The benefits of play are recognized by the scientific community. There is evidence now that neural pathways in children's brains are influenced and advanced in their development through exploration, thinking skills, problem solving, and language expression that occur during play.

Research also demonstrates that play-based learning leads to greater social, emotional and academic success. Based on such evidence, ministers of education endorse a sustainable pedagogy for the future that does not separate play from learning but brings them together to promote creativity in future generations. In fact, play is considered to be so essential to healthy development that the United Nations has recognized it as a specific right for all children.

\section{Learning Through Play is Supported by Experts}

Learning through play is supported by early years experts. Lev Vygotsky identified play as the leading source of development in terms of emotional, social, physical, language, and cognitive development. Play is not only our creative drive; it is a fundamental mode of learning (Wood, 2004).

Such experts recognize that play and academic work are not distinct categories for young children: creating, doing and learning are inextricably linked. When children are engaged in purposeful play, they are discovering, creating, improvising and expanding their learning. Viewing children as active participants in their own development and learning allows educators to move beyond preconceived expectations about what children should be learning, and focus on what they are learning.

\section{Learning Through Play is Supported by Children and Parents}

Learning through play is supported by children. It is their natural response to the environment around them. When children are manipulating objects, acting out roles, or experimenting with different materials, they are engaged in learning through play. Play allows them to actively construct, challenge and expand their own understandings through making connections to prior experiences, thereby opening the door to new learning. Intentional play-based learning enables children to investigate, ask questions, solve problems and engage in critical thinking.

Play is responsive to each child's unique learning style and capitalizes on his or her innate curiosity and creativity. Play-based learning supports growth in the language and culture of children and their families.

\section{When Children are Playing,Children are Learning}

Given the evidence, CMEC believes in the intrinsic value and importance of play and its relationship to learning. Educators should plan with intention and create challenging, dynamic, playbased learning opportunities. 
Intentional teaching is the opposite of teaching by rote or continuing with traditions simply because things have always been done that way. Intentional teaching involves educators being deliberate and purposeful in creating play-based learning environments because when children are playing, children are learning.

\section{References}

Brown, A. L. \& Campione, J. C. (1994). Guided discovery in a community of learners. In K. McGilly(Ed.),Classroom lessons: Integrating cognitive theory $\mathcal{E}$ classroom practice(pp.229-287). Cambridge, MA: MIT.

CMEC. (September 2010). Report from the World Conference on Early Childhood Care and Education, Moscow, Russia Federation.

CMEC (2012). Statement on Play-Based Learning. Retrieved from www.cmec.ca/ Publications/Lists/Publications/Attachme nts/282/play-based learning_statement_ EN.pdf

Corter, C. \& Pelletier, J. (2010). Integrated early childhood services in Canada: Evidence from the better beginnings, Better Futures (BBBF) and Toronto First Duty (TFD) Projects. In R. E. Temblay, R. G. Barr, R. DeV. Peters, \& M. Boinin(Eds.), Encyclopedia on early childhood development. Retrieved from http://www.child-

encyclopedia.com/documents/CorterP etersANGxp1.pdf

Dahlberg, G., Moss, P., \& Pence, A. (1999).Beyond quality in early childhood education and care: Postmodern perspectives. London: Falmer Press.

Fenichel, E. (1991). Learning through supervision and mentorship to support the development of infants, toddlers and their families. Zero to Three, 12(2), 1-8.
Gananathan, R. (2011). Implications of full day kindergarten program policy on early childhood pedagogy and practice. International Journal of Child Care and Education Policy, 5(2), 33-45.

Gettinger, M., Stoiber, K.C.,\& Lange, J. (1999). Collaborative investigation of inclusive early education practices: A blueprint for teacher-researcher partnership. Journal of Early Intervention, 22(3), 257265.

Heckman, J. (2008). Schools, Skills and Synapses. Retrieved from www.heckman equation.org/content/resource/schools -skills-synapses

Janmohamed, Z., \& Pelletier, J. (2010). Implementing early learning programs in Ontario schools. OPC Register, 12(2), 17-20.

Ministry of Education. (2010). Full Day Early Learning Kindergarten Program. Toronto, Ontario: Queens Printer for Ontario.

Muennig, P., Robertson, D., Johnson, G., Campbell, F., Pungello, E. P., \& Neidell, M. (2011). The effect of an early education program on adult health: The Carolina Abecedarian project ramdomized controlled trial. American Journal of Public Health 101(3), 512-516.

OECD. (2012). Starting Strong III. Retrieved from http://www.oecd.org/edu/preschool andschool/startingstrongiii-aqualitytool boxforearlychildhoodeducationandcare. htm

Pascal, C. (2009). Every child, every opportunity: Curriculum and pedagogy for the early learning program. Toronto, Ontario: Queens Printer for Ontario.

Pascal, C. (2009). With our best future in mind. Retrieved from http://www.ontario.ca/ education-and-training/early-learningreport

Wood, E.(2004). Developing a pedagogy of play. In J. Cullen(Ed.), Early childhood education: Society and culture. London, UK: Sage.

UN. (2005). Fact Sheet: A summary of the rights under the convention on the rights of the child. Retrieved from http://www.unicef.org/crc/files/Rig hts_overview.pdf 